Journal of Agricultural Sciences
(Tarim Bilimleri Dergisi)

\title{
Reducing Ammonia Volatilization from Urea Fertilizer Applied in a Waterlogged Tropical Acid Soil via Mixture of Rice Straw and Rice Husk Biochars
}

\author{
Gunavathy SELVARAJH ${ }^{\mathbb{D}}$, Huck Ywih CH'NG $^{\text {a* }}$ (D)

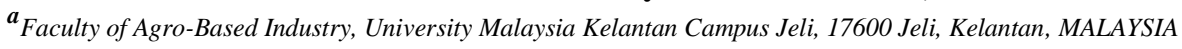 \\ ARTICLE INFO \\ Research Article \\ Corresponding Author: Huck Ywih CH’NG, E-mail: huckywih@umk.edu.my \\ Received: 07 December 2020 / Revised: 18 May 2021 / Accepted: 19 May 2021 / Online: 25 March 2022
}

\section{ABSTRACT}

Nitrogen deficiency frequently occurs in agricultural soil because of ammonia volatilization to the environment, resulting in low urea-N use efficiency by plants. A laboratory incubation experiment was conducted to assess the effect of rice straw and rice husk biochar's on ammonia volatilization, soil $\mathrm{pH}$, exchangeable ammonium, and available nitrate in comparison to the urea without additives under waterlogged conditions. Application of rice straw and rice husk biochar's mixture at application rate $5-10 \mathrm{t} \mathrm{ha}^{-1}$ had significantly minimized ammonia volatilization by
$30.86 \%$ - 38.61\% over T1 (175 kg ha $\mathrm{kg}^{-1}$ urea). T2 (5 t ha-1) and T3 (10 $\left.\mathrm{t} \mathrm{ha}^{-1}\right)$ also had significantly increased retention of ammonium by $79 \%-95 \%$ and nitrate ions by $49 \%-51 \%$ over control. The treatments amended with biochar had successfully improved soil $\mathrm{pH}$ compared to T0 (soil only) and T1. Hence, the findings suggest that urea amended with rice straw and rice husk biochar's altered the nutrients level in the soil by minimizing ammonia loss to enhance nitrogen availability in waterlogged conditions.

Keywords: Ammonia volatilization, Biochar, Nitrogen, Urea, Ammonium

(C) Ankara University, Faculty of Agriculture

\section{Introduction}

Nitrogen $(\mathrm{N})$ is a vital soil nutrient essential for good and abundant plant growth (Hajdu 2020). The main source of $\mathrm{N}$ for the plant comes from the external input application. Currently, urea $(46 \% \mathrm{~N})$ is being used in rice field as a main $\mathrm{N}$ contributor due to its abundant availability and relatively low price compared to other $\mathrm{N}$ fertilizers. However, there is a major concern in using urea as a N source because it is easily hydrolyzed and volatilized to the environment (Soares et al. 2012; Sunderlage \& Cook 2018). Urea hydrolyzes upon contact with water and forms ammonia gas $\left(\mathrm{NH}_{3}\right)$ which is susceptible to atmospheric loss via volatilization process. Around $60 \%$ of urea volatilized in the form of $\mathrm{NH}_{3}$ to the environment (Sommer et al. 2004; Rochette et al. 2009). The emission of $\mathrm{NH}_{3}$ gas to the environment triggers air pollution, which harms living things. Besides, during the urea hydrolysis process, the formation of inorganic ammonium ion $\left(\mathrm{NH}_{4}^{+}\right)$speeds up. Retention of $\mathrm{NH}_{4}{ }^{+}$ion in the soil is relatively very poor due to the lack of binding-adsorptive agent. The $\mathrm{NH}_{3}$ volatilization and poor retention of inorganic- $\mathrm{N}$ ions become very problematic for both farmers and plants. Deficient of $\mathrm{N}$ to plants cause farmers to increase the application of urea fertilizer, whereby this practice is not economical, efficient and reliable for long term use since it creates an environmental problem and costly.

Hence, an organic amendment such as biochar is necessary to minimize $\mathrm{NH}_{3}$ loss to the environment. Biochar is a porous carbonaceous solid produced by charring or pyrolysis method of organic materials under oxygen-depleted environment (Lehmann \& Joseph 2015; Ding et al. 2016). Biochar can be produced by utilizing agricultural wastes that are easily accessible and abundant. Mansor et al. (2018) stated that rice residues such as rice straw and rice husk are being produced annually more than 7,518,073 tonnes and 926,886 tonnes, respectively. The wastes are abundant and being burnt continuously. Burning wastes is hazardous for both the environment and human. So, turning the rice residues waste into biochar could be a promising approach to achieve sustainable waste management and benefits agronomy.

Biochar has a huge potential to improve soil fertility either by direct supply of nutrients or by fixing nutrients from the external source followed by slow release of the adsorbed nutrients (Unger 2008). The porosity and larger surface area of the biochar helps in nutrients absorption from the soil, which directly improves soil fertility (Lehmann \& Joseph 2015). Biochar's surface area plays an essential role in binding cations, and anions (Atkinson et al. 2010; Chan \& Xu 2009) which directly increases nutrient retention in biochar amended soil (Gai et al. 2014). Biochar capable to adsorb ammonium $\left(\mathrm{NH}_{4}{ }^{+}\right)$and (nitrate) $\mathrm{NO}_{3}{ }^{-}$onto its surface, thus increase the presence of these ions in the soil for plant uptake. Besides, biochar has been said to increase the formation of $\mathrm{NH}_{4}{ }^{+}$and $\mathrm{NO}_{3}{ }^{-}$over $\mathrm{NH}_{3}$. Eventually, this reduces $\mathrm{NH}_{3}$ volatilization from applied urea fertilizer. 
Yeboah et al. (2009) reported that an increase in soil nutrient retention due to the application of biochar results in the reduction of total fertilizer requirements in agricultural soil. Moreover, the alkaline nature of biochar modifies the soil acidity. Yuan et al. (2011), stated that biochar could act as an alternative liming agent to modify the soil $\mathrm{pH}$ in a way that it fits the crop growth.

Previous researchers demonstrated that biochar comes in different properties based on feedstock, charring condition, and activation. This agrees with Spokas et al. (2012) who also stressed the need for further research on biochar's economic and agronomic benefits. Additionally, there is also a scarcity of information on green feedstock biochar in amending soil fertility by preventing $\mathrm{N}$ loss either in rice, cash crops or other agricultural fields. It is crucial to know the properties of rice husk biochar and its ability to retain nutrients. It is hypothesized that the use of biochar produced from rice straw and rice husk wastes can create a pool of negative charges to retain and chelate the positively-charged $\mathrm{NH}_{4}{ }^{+}$ions to prevent it from loss through $\mathrm{NH}_{3}$ volatilization. Over time, the sorbed $\mathrm{NH}_{4}{ }^{+}$ions on biochar will be gradually released and become available to plants and microorganisms. Biochar can also induce microbial immobilization of $\mathrm{N}$ into the soil. Hence, this study was carried out to determine the effect of mixing urea with mixtures of rice straw and rice husk biochar on $\mathrm{NH}_{3}$ volatilization, exchangeable soil $\mathrm{NH}_{4}{ }^{+}$, and available $\mathrm{NO}_{3}{ }^{-}$as compared to the application of urea alone under a waterlogged condition.

\section{Material and Methods}

\subsection{Soil sampling, preparation and characterization}

The soil used in this study was Renggam sandy clay loam (Typic Paleudult). It was sampled at 0-30 cm from a land at the Agro Techno Park in University Malaysia Kelantan Jeli Campus, Malaysia (5 $5^{0} 44^{\prime} 69.55^{\prime}$ N latitude and $101^{0} 51^{\prime} 83.89$ ” E longitude) has not been cultivated since 2007. The collected soil was air-dried, crushed, and sieved to pass through a 2-mm sieve for initial soil characterization. Soil pH was measured in a ratio of 1:10 (soil:water) using a digital pH meter (Peech 1965). Soil texture was determined using the hydrometer method (Bouyoucos 1962). Total organic matter content, ash content, and total organic carbon were determined using the loss-on ignition method (Tan 2005).

Total N was determined using the Kjeldahl method (Bremner 1965). The double acid method described by Mehlich (1953) was used to extract soil available $\mathrm{P}$ and exchangeable cations $(\mathrm{Ca}, \mathrm{Mg}, \mathrm{K}$, and $\mathrm{Na}$ ), after which the cations were determined using an Atomic Absorption Spectrophotometer (AAS) (Analyst 800, Perkin Elmer, Norwalk, USA). Soil available P was determined using molybdenum blue method (Murphy \& Riley 1962). The developed blue color was analyzed using a UV-VIS spectrophotometer (Thermo Scientific Genesys 20, USA) at $882 \mathrm{~nm}$ wavelengths. Soil cation-exchange capacity (CEC) was determined by the ammonium acetate leaching method (Cotteinie 1980). The exchangeable acidity and exchangeable aluminum $\left(\mathrm{Al}^{3+}\right)$ were determined by the acid-base titration method described by Rowell (1994). The method described by Keeney \& Nelson (1982) was used to extract exchangeable $\mathrm{NH}_{4}{ }^{+}$and available $\mathrm{NO}_{3}{ }^{-}$, after which the ions were determined via steam distillation (Tan 2005).

\subsection{Biochar production, activation and characterization}

Rice husk was collected from Pasir Puteh Rice Mill whilst rice straw was collected from Kemubu granary area, Kota Bharu, Malaysia. Two cylindrical kilns, a $200 \mathrm{~L}$ drum with removable chimney caps and an airtight $110 \mathrm{~L}$ drum were constructed for biochar production. The rice husk and rice straw were bulked separately inside the $110 \mathrm{~L}$ drum then, closed and placed in the middle of the $200 \mathrm{~L}$ drum, where the fire was kindled starting from the bottom of the drum. The residence time was 4 hours with the temperature ranging from $300-400{ }^{\circ} \mathrm{C}$ and left for cooling for 2 hours. The temperature inside the kiln was measured using Extech TM100 K/J (Single Input Thermometer, Waltham, Massachusetts, United States). Later, the pile of biochar sample was spread out for cooling. After this, the enrichment of biochar was carried out by soaking with 5\% chicken slurry for 7 days which later was dried and stored in a big container for further use. The enrichment of biochar with chicken slurry was crucial to further increase the nutrient content, alter the surface area, and increase the pore size (Selvarajh et al. 2021a). The enriched biochars were analyzed for $\mathrm{pH}$ (Peech 1965), CEC and total N (Bremner 1965). The single dry ashing method (Tan 2005) was used to extract nutrients from rice husk and rice straw biochar for analysis of $\mathrm{Ca}, \mathrm{Mg}, \mathrm{Na}, \mathrm{P}$, and $\mathrm{K}$ using an AAS (Analyst 800, Perkin Elmer, Norwalk, USA), while total P content was determined using the molybdenum blue method (Murphy and Riley 1962), after which the blue color developed was analyzed using a UV-VIS Spectrophotometer (Thermo Scientific Genesys 20, USA) (Murphy and Riley 1962). Total C was determined using the loss on ignition method (Tan 2005). Additionally, microanalysis through Scanning Electron Microscopy-attached with Energy Dispersive X-ray Spectroscopy analysis (SEM-EDX JEOL JSM6400) was carried out analyze the surface morphology of enriched rice husk and rice straw biochar.

\subsection{Ammonia volatilization laboratory incubation study}

For laboratory-scale $\mathrm{NH}_{3}$ volatilization study, the actual amount of urea applied was $0.7 \mathrm{~g}$, scaled down from the $175 \mathrm{~kg}$ ha ${ }^{-1}$ application rate. The rice husk and rice straw biochar (1:1 ratio) actual application for $100 \mathrm{~g}$ of soil, scaled-down from 5, 10, 15, and $20 \mathrm{t} \mathrm{ha}^{-1}$ was $2.8 \mathrm{~g}, 5.5 \mathrm{~g}, 8.3 \mathrm{~g}$, and $11.1 \mathrm{~g}$, respectively. The treatments evaluated were listed in Table 1. Soil, urea, and biochar were mixed well before deposited into $250 \mathrm{~mL}$ conical flask, after which water was added to create a waterlogged condition. The water level was maintained $3 \mathrm{~cm}$ above the soil throughout the study. This set up was done to depict the 
waterlogged condition in the actual rice field. The system was set to be a closed dynamic airflow system, and the $\mathrm{NH}_{3}$ loss from urea was measured daily (Siva et al. 1999; Ahmed et al. 2006a, 2006b). The system includes a $250 \mathrm{~mL}$ conical flask exchange chamber containing soil mixture and a trap $250 \mathrm{~mL}$ conical flask chamber containing $75 \mathrm{~mL}$ of boric acid, which were stoppered and fit with inlet/outlet pipes. The chamber inlet containing the water was connected with an aquarium air pump and outlet connected with pipe tubing to the trap containing boric acid solution. Air was passed through the chambers at a rate of $2.75 \mathrm{~L}^{-1}$ $\min ^{-1}$ chamber $^{-1}$. This setup was done to create soil aeration and trap $\mathrm{NH}_{3}$ loss via volatilization process. The released $\mathrm{NH}_{3}$ was captured in the trapping solution containing $75 \mathrm{~mL}$ of boric acid with colour indicator. The incubation chambers Boric acidindicator traps were replaced every $24 \mathrm{~h}$ and back, titrated with a size of $0.01 \mathrm{M} \mathrm{HCl}$, to estimate the $\mathrm{NH}_{3}$ released. Measurement was continued until the loss declined to $1 \%$ of the $\mathrm{N}$ added with urea (Ahmed et al. 2008) After the $\mathrm{NH}_{3} \mathrm{volatilization}$ was evaluated, the soil samples were used for $\mathrm{pH}$, exchangeable $\mathrm{NH}_{4}{ }^{+}$and available $\mathrm{NO}_{3}{ }^{-}$determinations.

Table 1- Treatments evaluated in ammonia volatilization incubation study

\begin{tabular}{ll}
\hline Treatments & Description \\
\hline T0 & Soil only \\
T1 & Soil $+175 \mathrm{~kg} \mathrm{ha}^{-1}$ urea \\
T2 & Soil $+175 \mathrm{~kg} \mathrm{ha}^{-1}$ urea $+2.5 \mathrm{t} \mathrm{ha}^{-1}$ rice husk biochar $+2.5 \mathrm{t} \mathrm{ha}^{-1}$ rice straw biochar \\
T3 & Soil $+175 \mathrm{~kg} \mathrm{ha}^{-1}$ urea $+5 \mathrm{t} \mathrm{ha}^{-1}$ rice husk biochar $+5 \mathrm{t} \mathrm{ha}^{-1}$ rice straw biochar \\
T4 & Soil $+175 \mathrm{~kg} \mathrm{ha}^{-1}$ urea $+7.5 \mathrm{t} \mathrm{ha}^{-1}$ rice husk biochar $+7.5 \mathrm{t} \mathrm{ha}^{-1}$ rice straw biochar \\
T5 & Soil $+175 \mathrm{~kg} \mathrm{ha}^{-1}$ urea $+10 \mathrm{t} \mathrm{ha}^{-1}$ rice husk biochar $+10 \mathrm{t} \mathrm{ha}^{-1}$ rice straw biochar \\
\hline
\end{tabular}

\subsection{Statistical analysis}

The experiments were arranged in a completely randomized design with three replicates. The effect of different rice husk and rice straw biochar addition rates was subjected to one-way analysis of variance (ANOVA). Statistical analysis for all the data was performed using SPSS software version 24.0 (SPSS Inc, US). Significant differences among treatments were separated by Tukey's HSD test and considered significant at $\mathrm{P} \leq 0.05$.

\section{Result and Discussion}

\subsection{Selected soil physico-chemical properties}

The selected soil physico-chemical properties used in this study are presented in Table 2 . The soil showed a sandy clay loam texture with $\mathrm{pH}$ of 5.5. The soil showed relatively high $\mathrm{Al}\left(1.14 \mathrm{cmol}_{\mathrm{c}} \mathrm{kg}^{-1}\right)$ concentrations and Fe $\left(0.091 \mathrm{cmol}_{\mathrm{c}} \mathrm{kg}^{-1}\right)$ due to low soil $\mathrm{pH}$. This condition correlates to the lesser $\mathrm{P}$ availability $(0.385 \mathrm{ppm})$ in soil because of $\mathrm{P}$ fixation by $\mathrm{Al}$ and $\mathrm{Fe}$. Exchangeable $\mathrm{K}, \mathrm{Ca}, \mathrm{Mg}$, and $\mathrm{Na}$ was low in the soil due to the soil's lower CEC $\left(5.4 \mathrm{cmol}_{\mathrm{c}} \mathrm{kg}^{-1}\right)$. Lower CEC of the soil leads to inefficient nutrient holding and retention capacity of basic cations. The content of $\mathrm{N}(0.07 \%), \mathrm{NH}_{4}^{+}\left(89 \mathrm{ppm}^{+}\right.$, and $\mathrm{NO}_{3}^{-}(30 \mathrm{ppm})$ in the soil were low because of soil acidity, which slows down the mineralization process. Khalil et al. (2005) stated that acidic soil causes $\mathrm{N}$ immobilization instead of $\mathrm{N}$ mineralization. The soil used in this study needs amelioration to improve the soil quality and fits for crop growing.

Table 2- Selected soil physico-chemical properties

\begin{tabular}{|c|c|}
\hline Property & Value obtained \\
\hline pH & 5.5 \\
\hline $\mathrm{EC}\left(\mathrm{dS} \mathrm{m^{-1 } )}\right.$ & 0.022 \\
\hline Texture & Sandy clay loam \\
\hline Soil organic matter $(\%)$ & 6.24 \\
\hline Total Carbon (\%) & 3.62 \\
\hline Ash content (\%) & 6.4 \\
\hline Cation exchange capacity $\left(\mathrm{cmol}_{\mathrm{c}} \mathrm{kg}^{-1}\right)$ & 5.4 \\
\hline Ammonium (ppm) & 89 \\
\hline Nitrate (ppm) & 30 \\
\hline Total N (\%) & 0.07 \\
\hline Available P (ppm) & 0.385 \\
\hline Exchangeable K ( cmol $\left._{\mathbf{c}} \mathbf{~ k g}^{-1}\right)$ & 0.084 \\
\hline Exchangeable Ca $\left(\mathrm{cmol}_{\mathrm{c}} \mathrm{kg}^{-1}\right)$ & 0.10 \\
\hline Exchangeable $\mathrm{Mg}\left(\mathrm{cmol}_{\mathrm{c}} \mathrm{kg}^{-1}\right)$ & 0.082 \\
\hline Exchangeable Fe (cmolc kg-1) & 0.091 \\
\hline Exchangeable acidity $\left(\mathrm{cmol}_{\mathrm{c}} \mathrm{kg}^{-1}\right)$ & 0.7 \\
\hline Exchangeable Al $\left(\mathrm{cmolc} \mathrm{kg}^{-1}\right)$ & 1.14 \\
\hline
\end{tabular}




\subsection{Characterization of rice husk and rice straw biochars}

The surface morphological characteristics of rice husk biochar and rice straw biochar are shown in Figure 1 and Figure 2. Both rice straw and rice husk biochar composed of numerous pores and comes with a high surface area. This property is highly beneficial for agronomical practices in terms of increasing nutrient retention and boosting crop growth. Biochar's porous structure and bigger surface area help in binding ions from soil and external inputs. Lin et al. (2012) stated that biochar's high porous structure might have extractable humic-like and fluvic-like substances that act as chelators. Humic and fluvic acid restrict toxins in the soil by reducing harmful substances to reach the crop roots. Besides, biochar has a high surface area with a strong affinity to attract inorganic ions (Schmidt et al. 2015). This would be a great advantage in the agriculture field to bind nutrients from the soil and release it slowly as it degrades. The capability of biochar to bind nutrients also related to the higher CEC value, where rice straw biochar and rice husk biochar $\mathrm{CEC}$ is $75.6 \mathrm{cmol}_{\mathrm{c}} \mathrm{kg}^{-1}$ and $66.6 \mathrm{cmol}_{\mathrm{c}} \mathrm{kg}^{-1}$, respectively (Table 3). Biochar with higher CEC value adsorb more nutrients onto its surface and minimize volatilization. Not only that, the alkaline nature of both biochars $(\mathrm{pH}>9)$ can act as natural liming agent to reduce the acidity of soil at a certain application rate. The biochar also inherently packed with nutrients such as $\mathrm{N}, \mathrm{P}, \mathrm{K}, \mathrm{Ca}, \mathrm{Mg}$, and $\mathrm{Na}$. Eventually, the nutrients in biochar will be released to the soil for effective utilization by plants.

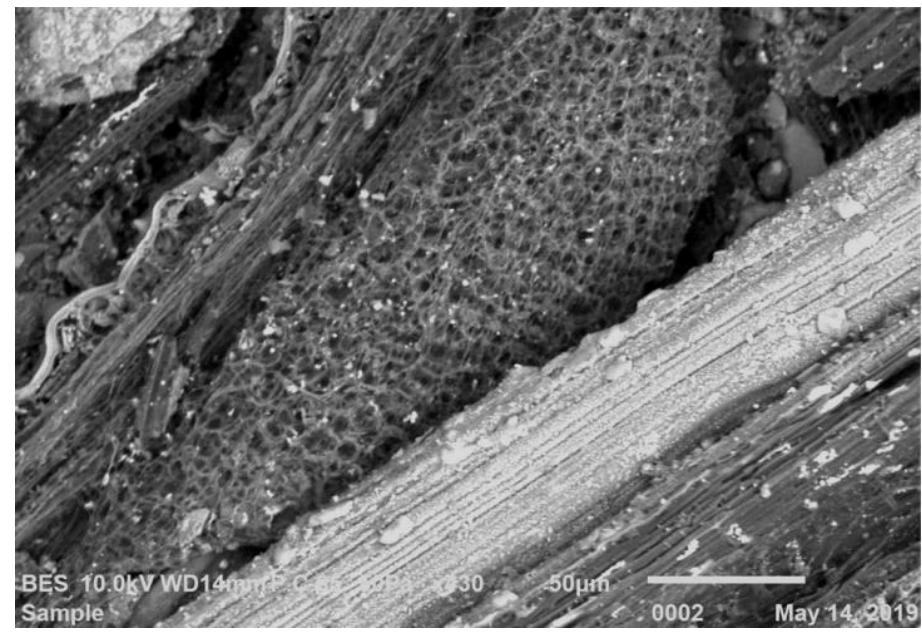

Figure 1- Rice husk biochar surface at 550x, magnification under SEM

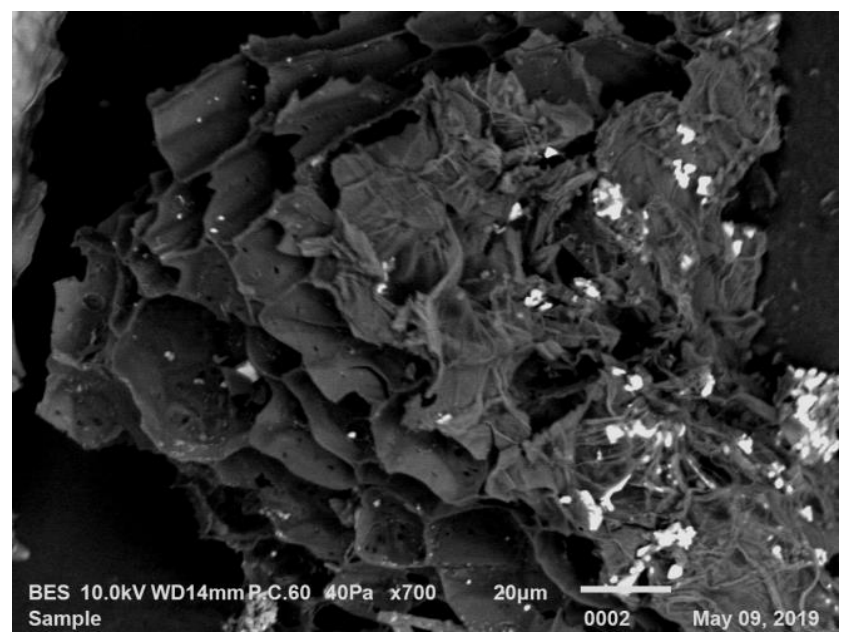

Figure 2- Rice straw biochar surface at 730x, magnification under SEM

Table 3- Selected physico-chemical properties of rice straw and rice husk biochar

\begin{tabular}{|c|c|c|}
\hline Property & Rice straw biochar & Rice husk biochar \\
\hline pH (water) & 9.2 & 9.1 \\
\hline CEC $\left(\mathrm{cmol} \mathrm{kg}^{-1}\right)$ & 75.6 & 66.6 \\
\hline Total Nitrogen (\%) & 0.45 & 0.33 \\
\hline Available P (ppm) & 14.3 & 14.3 \\
\hline Exchangeable Ca $\left(\mathrm{cmol}_{\mathrm{c}} \mathrm{kg}^{-1}\right)$ & 0.98 & 0.21 \\
\hline Exchangeable $\mathrm{Mg}\left(\mathrm{cmol}_{\mathrm{c}} \mathrm{kg}^{-1}\right)$ & 0.58 & 0.27 \\
\hline Exchangeable K $\left(\mathrm{cmol}_{\mathrm{c}} \mathrm{kg}^{-1}\right)$ & 7.68 & 2.51 \\
\hline Exchangeable $\mathrm{Na}\left(\mathrm{cmol}_{\mathrm{c}} \mathrm{kg}^{-1}\right)$ & 0.04 & 0.05 \\
\hline
\end{tabular}




\subsection{Combined effect of rice husk and rice straw biochars on $\mathrm{NH}_{3}$ volatilization}

The daily $\mathrm{NH}_{3}$ volatilization from urea fertilizer during the incubation study over 28 days is presented in Figure 3 . $\mathrm{NH}_{3}$ loss started on day 2 of incubation in treatment T1, on day 7 for T2 and T3, day 6 for T4 and T5, while no loss was found for T0. The delayed loss upon urea application shows the efficacy of added rice straw and rice husk biochars as an organic amendment in minimizing $\mathrm{NH}_{3}$ formation. The $\mathrm{NH}_{3}$ loss from urea can be delayed for 3-6 days with the addition of organic materials (Omar et al. 2010). The maximum $\mathrm{NH}_{3}$ loss for $\mathrm{T} 1$ occurred on day 5, T2 on day 12, T3 on day 13, T4 on day 11 , and $\mathrm{T} 5$ on day 13 . The graph shows that $\mathrm{NH}_{3}$ loss peaks up and reduces gradually up to $28^{\text {th }}$ day until $\mathrm{N}$ added as urea ceases up to $1 \%$. Rapid $\mathrm{NH}_{3}$ loss in $\mathrm{T} 1$ was probably due to increased soil $\mathrm{pH}$ as urea hydrolysis leads to hydrogen ions $\left(\mathrm{H}^{+}\right)$from the soil solution. However, in treatment amended with rice straw and rice husk biochar, the $\mathrm{NH}_{3}$ loss was minimal due to the increased formation of $\mathrm{NH}_{4}{ }^{+}$over $\mathrm{NH}_{3}$ in the soil. Besides, Dougherty et al. (2017) stated that biochar's addition minimizes $\mathrm{NH}_{3}$ volatilization by increasing the $\mathrm{NH}_{3}$ adsorption at the oxygen-containing surface functional group or biochar micropores.

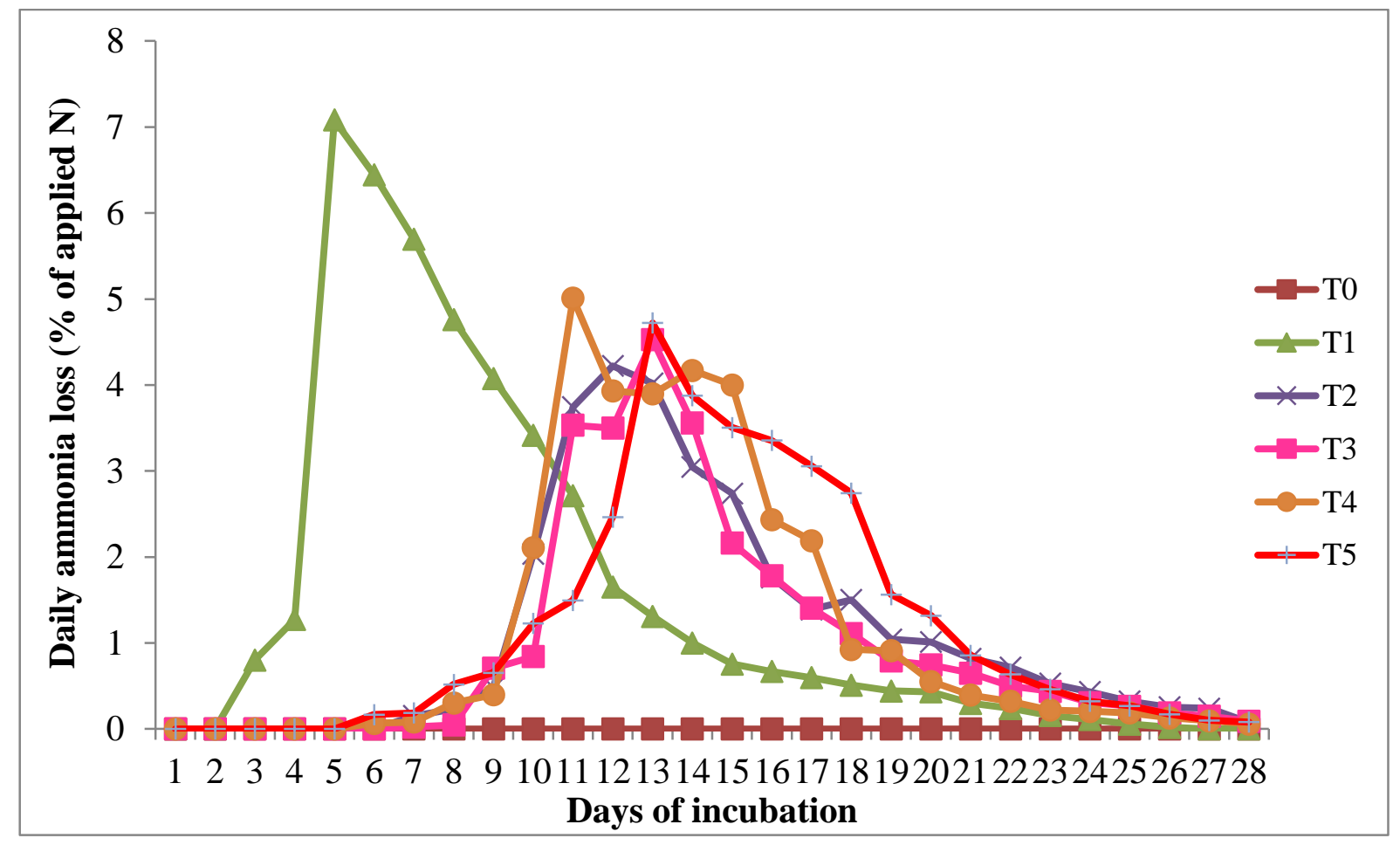

Figure 3- Ammonia volatilization over 28 days of incubation under waterlogged condition

The treatments with biochar as an additive (T2, T3, T4, and T5) had significantly minimized $\mathrm{NH}_{3}$ loss compared to urea without additives (T1) (Figure 4). The total amounts of $\mathrm{NH}_{3}$ lost at the end of the incubation period as a percentage of urea-N added were $0,44.52,30.79,27.33,32.62$, and $33.66 \%$ for T0, T1, T2, T3, T4, and T5, respectively. Noticeably, T2 and T3 were significantly effective in minimizing $\mathrm{NH}_{3}$ loss over $\mathrm{T} 1$. Irrespective of the application rate, all the treatments with biochar as an additive had effectively reduced $\mathrm{NH}_{3}$ loss compared to T1. Addition of porous biochar with larger surface area delayed and minimized $\mathrm{NH}_{3}$ loss due to its capability to bind more $\mathrm{NH}_{4}{ }^{+}$and $\mathrm{NO}_{3}{ }^{-}$ions (Figures 6 and 7). This was in agreement with a study conducted by Chen et al. (2013). Besides, biochar increases the soil volume and pore size and stabilize the soil aggregate (Burrell et al. 2016). Since the volume of soil increased with which urea is mixed, it will also increase the time required for complete urea hydrolysis (Fan \& Mackenzie 1993). Delays in urea hydrolysis due to the biochar application can minimize N loss, which will benefit plants in the agricultural field. 


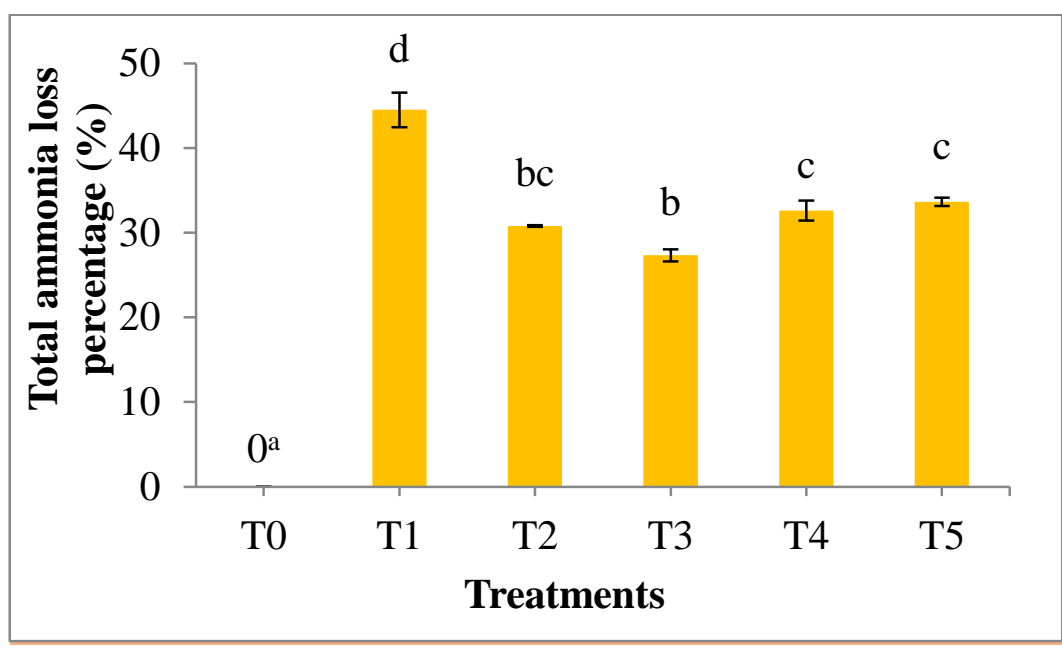

Figure 4- Total $\mathrm{NH}_{3}$ losses from incubation study under waterlogged conditions.

Besides, biochar has alkaline nature where it can act as a liming agent to reduce soil acidity. Treatments with biochar had improved soil pH (Figure 5). Ch'ng et al. (2016) and Tang et al. (1999) stated that an increase in the soil pH was due to the rapid proton exchange between soil and biochars. The increase in soil $\mathrm{pH}$ is also related to the release of anions from rice straw and rice husk biochar, where anions undergo decarboxylation and exchange of protons in soil. In the previous study, it has been reported that $\mathrm{NH}_{3}$ volatilization speeds up in soil with higher $\mathrm{pH}$ (Sun et al. 2019), but contrastingly in this study, the added biochars minimized the volatilization. This is due to the nutrients' adsorptive capability of the rice straw and rice husk biochars. Selvarajh et al. (2021b) also stated that increased soil pH due to biochar's addition does not significantly trigger ammonia loss.

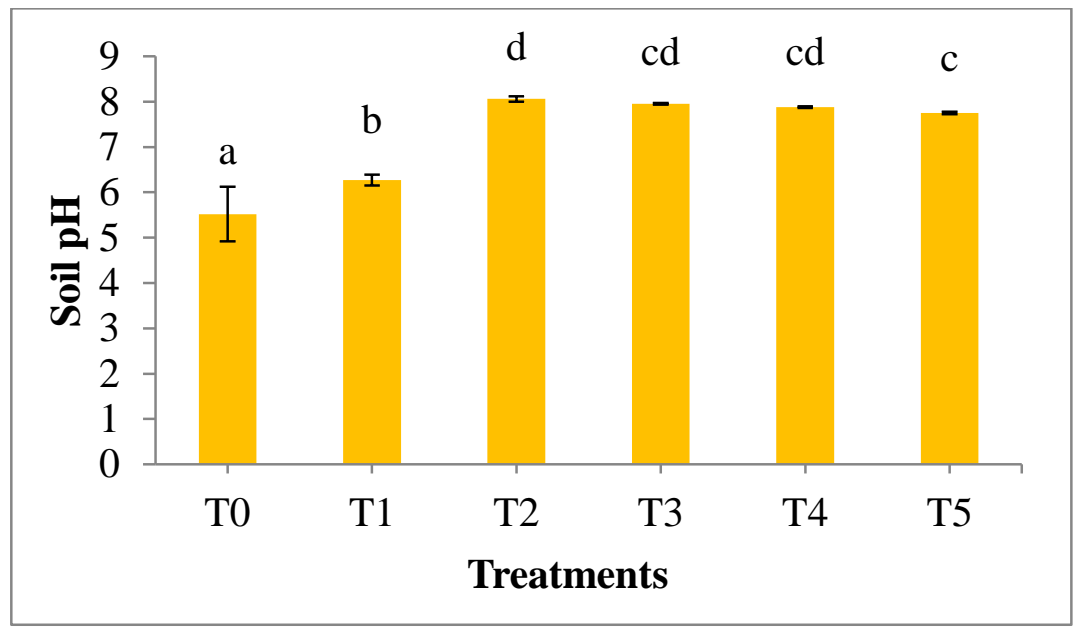

Figure 5- Soil pH after incubation study

Additionally, biochar had successfully sorb nutrients from the soil. T2, T3 and T4 had shown significant $\mathrm{NH}_{4}^{+}$retention in soil over T0, T1, and T5 (Figure 6). T2 and T3 had retained the highest amount of $\mathrm{NH}_{4}{ }^{+}$by $95 \%$ and $79 \%$ respectively over T1, followed by T4 and T5, which is $54 \%$ and $12 \%$. This shows that the biochar had increased the formation of $\mathrm{NH}_{4}{ }^{+}$ions over $\mathrm{NH}_{3}$. Besides, the nitrate ions in the soil are found to be higher. The T2 and T3 had retained more amount of $\mathrm{NO}_{3}{ }^{-}$by $51 \%$ and $49 \%$, respectively, compared to T1, followed by T4 and T5 which is $23 \%$ and $9 \%$ (Figure 7). Biochar retains more charged ions because it has zwitterions properties that bind ions on its surface (Waters et al. 2010). Another reason for the higher retention of $\mathrm{NH}_{4}{ }^{+}$could be associated with the higher CEC of rice husk and rice straw biochar, $66.6 \mathrm{cmol}_{\mathrm{c}} \mathrm{kg}^{-1}$ and $75.6 \mathrm{cmol}_{\mathrm{c}} \mathrm{kg}^{-1}$, respectively absorbs the ions and releases it slowly. This was in agreement with Omar et al. (2010). The higher content of $\mathrm{NH}_{4}{ }^{+}$ and $\mathrm{NO}_{3}{ }^{-}$suggest that the inclusion of combined biochar of rice husk and rice straw had improved the presence of nutrients in the soil for uptake by plants. 


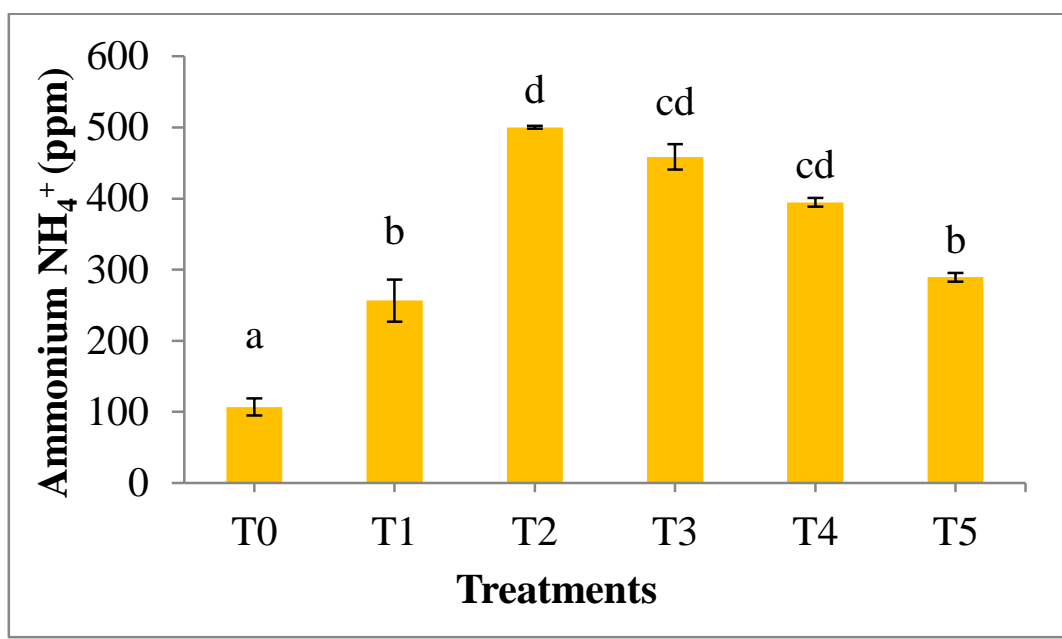

Figure 6- Ammonium $\left(\mathrm{NH}_{4}{ }^{+}\right)$retention in soil after incubation study.

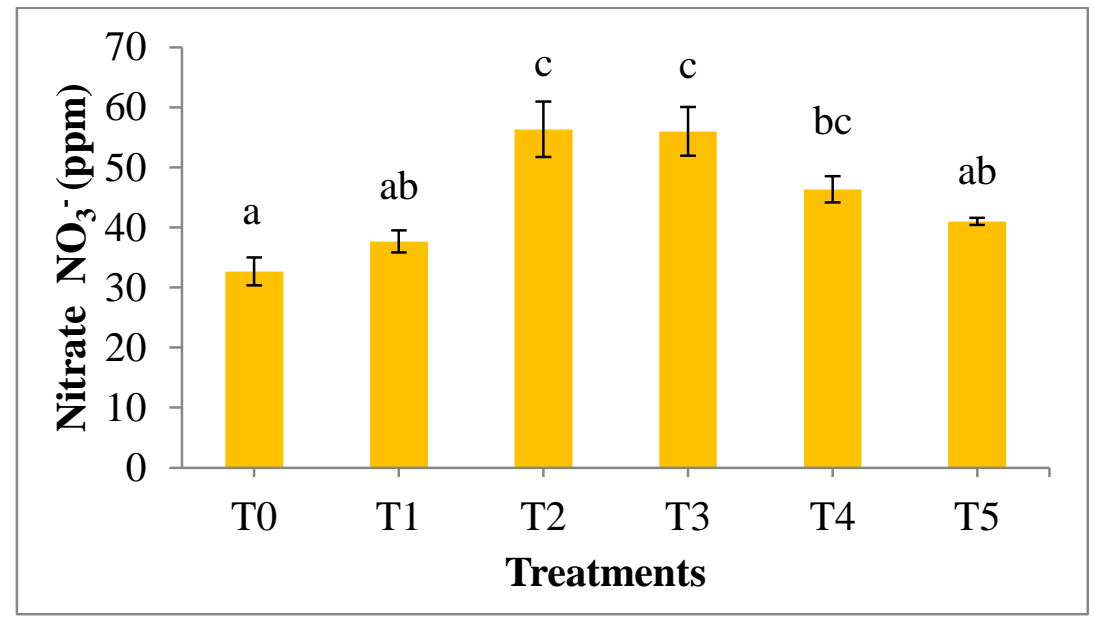

Figure 7- Nitrate $\left(\mathrm{NO}_{3}^{-}\right)$retention in soil after incubation study.

Note: Mean values with different letter(s) indicate significant difference between treatments by Tukey's test at $\mathrm{P} \leq 0.05$. Bars represent the mean values $\pm \mathrm{SE}$.

\section{Conclusions}

The result of this study suggests that the application of urea with a mixture of rice straw and rice husk biochars at the rates of 5 $\mathrm{t} \mathrm{ha}^{-1}$ and $10 \mathrm{t} \mathrm{ha}^{-1}$ offers a significant advantage over urea alone. The biochar mixtures have effectively retained more $\mathrm{NH}_{4}{ }^{+}$and $\mathrm{NO}_{3}{ }^{-}$ions in the soil by minimizing conversion to $\mathrm{NH}_{3}$ even at increased soil $\mathrm{pH}$ levels. This leads to a significant reduction in $\mathrm{NH}_{3}$ released into the atmosphere. The addition of a mixture of rice straw and rice husk biochars retained more inorganic $\mathrm{N}$ in the soil. Eventually, this will lead to sustainable $\mathrm{N}$ management in rice production and prevent greenhouse $\mathrm{NH}_{3}$ gas emissions.

\section{Acknowledgements}

The authors would like to thank Malaysia Ministry of Education and Malaysia Ministry of Finance for financial assistance and Universiti Malaysia Kelantan Jeli Campus for providing research facilities. This research was supported by grants from the Malaysia Fundamental Research Grant Scheme (FRGS) (Grant. No.: FRGS/1/2018/WAB01/UMK/02/1).

\section{References}

Ahmed O H, Aminuddin H \& Husni M H A (2006a). Effects of urea, humic acid and phosphate interactions in fertilizer microsites on ammonia volatilization and soil ammonium and nitrate contents. International Journal of Agricultural Research (1): 25-31. https://doi.org/10.3923/ijar.2010.370.376

Ahmed O H, Aminuddin H \& Husni M H A (2006b). Reducing ammonia loss from urea and improving soil-exchangeable ammonium retention through mixing triple superphosphate, humic acid and zeolite. Soil Use Management 22(3): 315-319. https://doi.org/10.1111/j.14752743.2006.00040.x

Ahmed O H, Husin A \& Hanif A H M (2008). Ammonia volatilization and ammonium accumulation from urea mixed with zeolite and triple superphosphate. Acta Agriculturae Scandinavica, Section B - Soil \& Plant Science 58(2): 182-186. https://doi.org/10.1080/09064710701478271 
Atkinson C J, Fitzgerald J D \& Hipps N A (2010). Potential mechanisms for achieving agricultural benefits from biochar application to temperate soils: a review. Plant and Soil 337(1-2): 1-18. https://doi.org/10.1007/s11104-010-0464-5

Bremner J M (1965). Organic forms of nitrogen. In: Black CA (ed.) Methods of Soil Analysis. Agronomy 9: 1238-1254

Bouyoucos G J (1962). Hydrometer method improved for making particle size analyses of soils. Agronomy Journal 54: 464-65.

https://doi.org/10.2134/agronj1962.00021962005400050028x

Burrell L D, Zehetner F, Rampazzo N, Wimmer B \& Soja G (2016). Long-term effects of biochar on soil physical properties. Geoderma 282: 96-102. https://doi.org/10.1016/j.geoderma.2016.07.019

Chan K Y \& Xu Z B (2009). Nutrient properties and their enhancement. Biochar for Environmental Management: Science and Technology $67-84$

Chen C R, Phillips I R, Condron L M, Goloran J, Xu Z H \& Chan K Y (2013). Impacts of greenwaste biochar on ammonia volatilisation from bauxite processing residue sand. Plant Soil 367: 301-12. https://doi.org/10.1007/s11104-012-1468-0

Ch'ng H Y, Ahmed O H \& Majid M N A (2016). Improving phosphorus availability, nutrient uptake and dry matter production of Zea mays L. on a tropical acid soil using poultry manure biochar and pineapple leaves compost. Experimental Agriculture 52(3): 447. https://doi.org/10.1017/s0014479715000204

Cotteinie A (1980). Soil testing and plant testing as a basis of fertilizer recommendation. FAO Soils Bulletin 38:70-73

Ding Y, Liu Y, Liu S, Li Z, Tan X, Huang X, Zeng G \& Zheng B (2016). Biochar to improve soil fertility. A review. Agronomy for Sustainable Development 36(2): 36. https://doi.org/10.1007/s13593-016-0372-Z

Dougherty B W, Gray M, Johnson M G \& Kleber M (2017). Can biochar covers reduce emissions from manure lagoons while capturing nutrients? Journal of Environmental Quality 46(3): 659-666

Fan M X \& Mackenzie A F (1993). Urea and phosphate interactions in fertilizer microsites: Ammonia volatilization and pH changes. Soil Science Society of America Journal 57: 839-845. https://doi.org/10.2136/sssaj1993.03615995005700030034x

Gai X, Wang H, Liu J, Zhai L, Liu S, Ren T \& Liu H (2014). Effects of feedstock and pyrolysis temperature on biochar adsorption of ammonium and nitrate. PloS one 9(12). e113888. https://doi.org/10.1371/journal.pone.0113888

Hajdu I (2020). Macronutrients Play a Vital Role In Crop Production. Retrieved March 29, 2020 from https://blog.agrivi.com / post/ macronutrients- play-a- vital-role-in- crop-production.

Keeney D R \& Nelson D W (1982). Nitrogen-Inorganic forms. In: Miller AL, Keeney DR (eds.) Methods of Soil Analysis part 2: Chemical and microbiological properties, American society of Agronomy, Madison, WI, pp. 643-698. https://doi.org/10.2134/agronmonogr9.2.2ed.c33

Khalil M I, Hossain M B \& Schmidhalter U (2005). Carbon and nitrogen mineralization in different upland soils of the subtropics treated with organic materials. Soil Biology and Biochemistry 37(8): 1507-1518. https://doi.org/10.1016/j.soilbio.2005.01.014

Lehmann J \& Joseph S (2015). Biochar for environmental management: An Introduction. In Biochar for Environmental Management, (pp. 3346). Routledge

Lin Y, Munroe P, Joseph S, Henderson R \& Ziolkowski A (2012). Water extractable organic carbon in untreated and chemical treated biochars. Chemosphere 87(2): 151-157. https://doi.org/10.1016/j.chemosphere.2011.12.007

Mansor A M, Theo W L, Lim J S, Ani F N, Hashim H and Ho W S (2018). Potential commercialisation of biocoke production in Malaysia-A best evidence review. Renewable and Sustainable Energy Reviews 90: 636-649. https://doi.org/10.1016/j.rser.2018.03.008

Mehlich A (1953). Determination of P, Ca, Mg, K, Na and NH4. Releigh, North Carolina State University Soil Test Division.

Murphy J \& Riley J P (1962). A modified single solution method for the determination of phosphate in natural waters. Analytical Chimica Acta 27: 31-36. https://doi.org/10.1016/s0003-2670(00)88444-5

Omar O L, Ahmed O H \& Muhamad A N (2010). Minimizing ammonia volatilization in waterlogged soils through mixing of urea with zeolite and sago waste water. International Journal of Physical Sciences 5(14): 2193-2197

Peech H M (1965). Hydrogen-ion activity. In: Methods of soil analysis, part 2, Black CA, Evans DD, Ensminger LE, et al. Madison, WI: American Society of Agronomy

Rochette P, MacDonald J D, Angers D A, Chantigny M H, Gasser M O, Bertrand N (2009). Banding of urea increased ammonia volatilization in a dry acidic soil. Journal of Environmental Quality 38: 1383-1390. https://doi.org/10.2134/jeq2008.0295

Rowell D L (1994). Soil science, methods and applications. Longman Group UK Limited, pp. 86-87

Schmidt H P, Pandit B H, Martinsen V, Cornelissen G, Conte P \& Kammann C I (2015). Fourfold increase in pumpkin yield in response to low-dosage root zone application of urine-enhanced biochar to a fertile tropical soil. Agriculture 5: 723-741. https://doi.org/10.3390/agriculture5030723

Selvarajh G, Ch'ng H Y \& Zain N M (2021a). Effects of rice husk biochar in minimizing ammonia volatilization from urea fertilizer applied under waterlogged condition [J]. AIMS Agriculture and Food 6: 159-171. https://doi.org/10.3934/agrfood.2021010

Selvarajh G, Ch'ng H Y, Md Zain N, Sannasi P \& Azmin S N H M (2021b). Improving Soil Nitrogen Availability and Rice Growth Performance on a Tropical Acid Soil via Mixture of Rice Husk and Rice Straw Biochars. Applied Sciences 11: 108. https://doi.org/10.3390/app11010108

Siva K B, Aminuddin H \& Husni M H A (1999). Ammonia volatilization from urea as affected by tropical-based palm oil mill effluent (Pome) and peat. Communications in Soil Science and Plant analysis 30(5-6): 785-804. https://doi.org/10.1080/00103629909370246

Soares J R, Cantarella H \& De Campos Menegale M L (2012). Ammonia volatilization losses from surface-applied urea with urease and nitrification inhibitors. Soil biology and biochemistry 52: 82-89. https://doi.org/10.1016/j.soilbio.2012.04.019

Sommer S G, Schjoerring J K \& Denmead O T (2004). NH3 emission from mineral fertilizers and fertilized crops. Advances in Agronomy 82: 557-622. https://doi.org/10.1016/s0065-2113(03)82008-4

Spokas K A, Novak J M, Venterea R T (2012). Biochar's role as an alternative N-fertilizer: ammonia capture. Plant \& Soil 350(1-2): 35-42. https://doi.org/10.1007/s11104-011-0930-8

Sun H, Zhang H, Xiao H, Shi W, Müller K, Van Zwieten L \& Wang H (2019). Wheat straw biochar application increases ammonia volatilization from an urban compacted soil giving a short-term reduction in fertilizer nitrogen use efficiency. Journal of Soils and Sediments, 19(4): 1624-1631. https://doi.org/10.1007/s11368-018-2169-y

Sunderlage B \& Cook R L (2018). Soil property and fertilizer additive effects on ammonia volatilization from urea. Soil Science Society of America Journal 82(1): 253-259. https://doi.org/10.2136/sssaj2017.05.0151

Tan K H (2005). Soil sampling, preparation, and analysis ( $2^{\text {nd }}$ ed). Boca Raton, Florida, USA 
Tang C, Sparling G P, McLay C D A \& Raphael C (1999). Effect of short-term legume residue decomposition on soil acidity. Australian Journal of Soil Research 237: 561-573. https://doi.org/10.1071/s98104

Unger R C (2008). The effect of bio-char on soil properties and corn grain yields in Iowa. Master of Science Thesis(Unpublished). https://doi.org/10.31274/etd-180810-3396

Waters D, Condon J, Van Zwieten L \& Moroni S (2010). Biochar-ion interactions: an investigation of biochar charge and its effect on ion retention. In $19^{\text {th }}$ World Congress of Soil Science.

Yeboah E, Ofori P, Quansah G W, Dugan E \& Sohi S P (2009). Improving soil productivity through biochar amendments to soils. African Journal of Environmental Science and Technology 3(2): 34-41

Yuan J H, Xu R K, Qian W \& Wang R H (2011). Comparison of the ameliorating effects on an acidic ultisol between four crop straws and their biochars. Journal of soils and sediments 11(5): 741-75. https://doi.org/10.1007/s11368-011-0365-0

(C) 2022 by the author(s). Published by Ankara University, Faculty of Agriculture, Ankara, Turkey. This is an Open Access article distributed under the terms and conditions of the Creative Commons Attribution (CC BY) license (http://creativecommons.org/licenses/by/4.0/), which permits unrestricted use, distribution, and reproduction in any medium, provided the original work is properly cited. 